Copyright (C) 2015 by Academic Publishing House Researcher

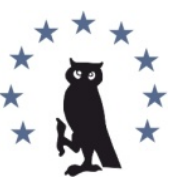

Published in the Russian Federation

European Researcher

Has been issued since 2010.

ISSN 2219-8229

E-ISSN 2224-0136

Vol. 93, Is. 4, pp. 270-281, 2015

DOI: $10.13187 / \mathrm{er} .2015 .93 .270$

www.erjournal.ru

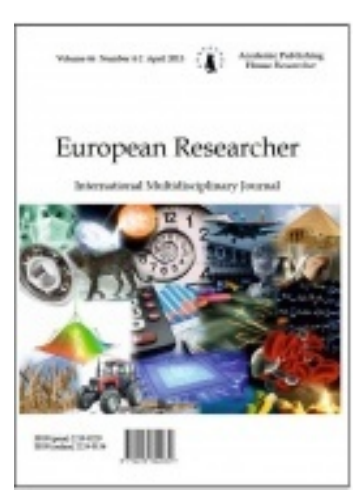

UDC 33

\title{
Role of Transformational Leadership on Employee's J ob Satisfaction: the Case of Private Universities in Bosnia and Herzegovina
}

${ }^{1}$ Hamidullah Bayram

${ }^{2}$ Sait Dinç

\author{
1-2 International Burch University \\ ${ }^{1}$ Research Assistant \\ E-mail: hamidullah.bayram@ibu.edu.ba \\ ${ }^{2}$ Lecturer, Assistant Professor \\ E-mail: m.sait.dinc@ibu.edu.ba
}

\begin{abstract}
The impact and type of effective leadership has a significant role in the improvement of organizational performance. This study has been conducted to indicate the importance of transformational leadership style on employees' job satisfaction. The aim of this study is to describe the relationship between transformational leadership and employees' job satisfaction at private universities in Bosnia and Herzegovina. A sample of 150 employees responded to a threepart instrument from two private universities in Sarajevo, the capital city of Bosnia and Herzegovina. Factor analysis, means, standard deviations, correlation and regression analysis were used to analyze the data. The findings determined that a moderate, positive and significant relationship exists between the dimensions transformational leadership and employees' job satisfaction for both work of nature and operating condition. This study suggests that leaders at the private universities should pay more attention to findings new analytical ways for old problems and describing the demand of followers.
\end{abstract}

Keywords: Transformational leadership; J ob satisfaction and Bosnia and Herzegovina.

\section{Introduction}

In today's business environment, organizational performance has been very crucial in order that organizations have been able to compete against their rivals. Therefore, a plenty of researchers have studied factors which influence the performance of organizations in business. Most of the findings in these studies have referred to the employee behaviors. At this point, one of the most important employee behaviors in affecting organizational performance is job satisfaction of employees. J ob satisfaction is a concept that concerns how an employee feels about a given job (Shin and Reyes, 1991). The studies which are related to job satisfaction generally indicate that if employees have good feelings about their job and are satisfied with their job, they will have a huge contribution to the organization. Thereby, identifying the determinants of job satisfaction attracted attention in many studies (Cohrs, Abele, and Dette, 2006).

Leadership has a distinct place in influencing job satisfaction. Pool (1997)'s research supported this by suggesting that leadership behavior is a predictor of job satisfaction. According to Bateman and Organ (1983), there is a strong relationship between satisfaction and supervision. 
The basis for this relationship is that supervisors in the organization represent the most direct source of variance in events that influence positive affect of employees. Moreover, from other leadership types, transformational leadership has been one of the most important determinants. Because, transformational leadership, as newly and more common model within current leadership styles, provide an opportunity that enriches the cooperation for leader, follower, and their success. Team performance within organization and high satisfaction with high motivation driven leaders are the primary characteristics of transformational leadership (Avolio, Bass, \& Jung, 1999). When transformational leaders who give special attention to their followers and care their needs more, the followers are more likely work towards achieving longer-term goals in order to meet the leader's expectations. Thus, this situation results in increased job satisfaction (Walumbwa, Orwa, Wang, Lawler, 2005). On the other hand, although abundant studies show the relationship between transformational leadership behaviors and employees' job satisfaction (Podsakoff, MacKenzie, Moorman, and Fetter, 1990), there is a scarce literature which stress on transformational leadership components and job satisfaction relationship.

However, many empirical studies about the relationship between leadership styles and employees' job satisfaction have been conducted in different sectors such as banking sector (Awanleh \& Al-Dmour, 2004; Belias \& Koustelios, 2014), health sector (Kuzey, 2012; Lorber \& Savic, 2012 and Peltier \& Dahl, 2009). But, limited literature has focused on this relationship in education sector. For example, in Amorosso (2002)'s study, it is proposed that the higher job satisfaction of employees at educational institutions is strongly interconnected with leadership style. Among education organizations, whether there is strong relationship between job satisfaction of the employees at higher education institutions and leadership styles or not has awaken curiosity today. Universities which are from higher education institutions have become a role model in reforming leadership styles and its quality. The focus point for these types of higher education organizations is transforming the behaviors and visions of the leaders and their follower. Rapid changes in transforming the practical experience with knowledge had been settled down at universities by role model leaders. "Knowledge work will dominate the $21^{\text {st }}$ century. It requires more envisioning, enabling, and empowering leadership, all of which are central to transformational leadership" (Bass, 1997; p. 131). On the other hand, even though the researches regarding transformational leadership and employees' job satisfaction relationship at universities have been done in developed countries, there is a scarcity of literature in developing countries.

One of these developing countries is Bosnia and Herzegovina $(\mathrm{BiH}) . \mathrm{BiH}$, as one of the former Yugoslavian countries, has experienced several big measured wards in its own region. It has been authorized under the control of big states: Ottoman Empire, Austria-Hungarian Empire, and Yugoslavia. Thus, Bosnia as a multi-ethnic society had big-scaled changes in its close history in the political, economic, cultural and educational context. Today, this inter-cultural relations and different ethnicities are counted as richness, weakness, and obstacles of $\mathrm{BiH}$ with different political structure such as federal rotation system. Along with rooted public institutions, private initiatives in business have been established since 2000's. Educational sector especially higher education in $\mathrm{BiH}$ has also encountered these developments. While this transitional country has eight rooted public universities, there are 38 private universities which have been established in last decade. Organizational structure and managerial part of these private universities in this small country has to be developed and enriched in the context of employee satisfaction in work and leadership styles. Thus, this paper will explore relationship between employees' job satisfaction and transformational leadership styles at private universities in $\mathrm{BiH}$.

\section{Literature review}

\subsection{J ob Satisfaction}

J ob satisfaction has been defined many times in a different way (Omar \& Hussin, 2013). In general, the concept of satisfaction is defined as one of the factors of overall pleasure of the performed job. This descriptive aspect needs to identify an employee with pleasure in the context of job satisfaction (Bota, 2013). According to Locke (1976), job satisfaction has been defined "as a pleasurable or positive emotional state resulting from the appraisal of one's job or job experiences" (Shrivastava \& Purang, 2009; p. 65). This pleasurable and positive emotion direct the employees 
for higher satisfaction. Thus, workplace and conditions are the most distinguished items to reach higher job satisfaction.

Nowadays, workplace and work conditions have more effective with globalization, technologies, economics situation (Shrivastava \& Purang, 2009). Both have significant effect for higher job satisfaction. That is why suitable workplace and good conditions are needed for the wellness of employees. Thus, the significance of higher job satisfaction is mostly based on workplace and its conditions with the management of organization (Bota, 2013). More satisfied employees are mostly part of accomplished organization by highly motivated management structure. For the managerial structure of an organization, principals/leaders have inevitable effect on employee's job satisfaction. (Judge, Bono, \& Locke, 2000). In this context, leadership and behavior of leaders have a significant effect on satisfaction of employees (Mirkamali, Thani, \& Alami, 2011; Omar \& Hussin, 2013).

\subsection{Leadership}

In general, the concept of leadership refers to be in interaction of superior with employee in every day (Belias \& Koustelios, 2014). The leadership is defined by Yukl (2006) as a process of influencing others and dealt with concept of what needs and how to do. Northouse (2007) has defined leadership as a process that contains influencing groups in order to achieve a mutual goal. Thus, content of leadership includes group context, goal success, and purpose sharing between leaders and their followers (Northouse, 2007). Fry (2003) claimed that leadership is the way of a strategy which leads inspirations, motivates and enriches the development of followers. This strategy is concluded with mentioned content of leadership in order to classify leadership. Recent findings of Luthans and Doh (2012) on leadership has been classified into three groups as Bass concluded the most interested efforts for Leadership: Transformational that refers to visionary sense with mission who are able to motivate their followers, Transactional that refers to "individuals who exchange rewards for effort and performance and work on a something for something basis" (p. 473); and Charismatic that refers to someone who can explore how individuals may have abilities to work by inspiration and motivation (p. 473). These are the new trend for universalism of leadership and human behaviors. In this approach to the leadership, according to Marn (2012), the leadership defined in Hackman and J ohnson's book as "human communication which modifies the attitudes and behaviors of others in order to meet shared group goals and needs" (p. 28). In terms of this definition, he pointed out that leadership might be differentiated transformational and transactional as they are most common ones; and both transformational and transactional are based on human moral, behaviors, employees in organizational climate as early leadership theorist argued, and ethics (Marn, 2012). This article will focus on transformational leadership due to transformational leadership is the most useful, effective, and common types for higher job satisfaction, as well as the most suitable leadership style for the relationship between leaders and their followers.

\subsection{Transformational Leadership}

The importance and role of transformational leadership has been well-described by Burns who is political scientist, over the time of 20 years ago as "an interconnected progress between leader and his/ her followers" (J ack \& Rudnick, 2007). It has been one of the most dominant and influenced leadership types since 1980's (Lim \& Ployhart, 2004). According to Burns, leaders and their followers are in interaction and they help each other in transforming way of leadership in order to reach a higher level of motivation (Jack \& Rudnick, 2007). Transformational leaders encourage their followers to have responsibilities to get higher organizational performance (Marn, 2012). Therefore, "after studying thousands of international cases, Bass found that the most effective managers were transformational leaders" (Luthans \& Doh, 2012: p. 474). In Bass' study, transformational leadership was also categorized for the first time as idealized influence (charisma) through which leader moves the follower beyond immediate self-interests, inspiration, intellectual stimulation, or individualized consideration (Bass, 1999). Transformational leadership types are developed by Luthans and Doh (2012) stated as idealized influence (charisma: can be also measured by two group as attributed and behavior), inspirational motivation, intellectual 
stimulation and individualized consideration. These transformational leadership dimensions can be summarized shortly as follows:

1. Idealized influence (attributed and behavior): "Leaders are admired, respected, and trusted" (Boerner, Eisenbeiss, \& Griesser, 2007: p. 16). This type of leaders deals with the admiration of their followers; it is also called "source of carisma". They enjoy loyalty, trust, and pride in their followers (Luthans \& Doh, 2012).

2. Inspirational motivation: It refers to the capacity to motivate followers to reach high expectations (Marn, 2012). Leaders who are in this category have ability in explanation of their vision, beliefs, and mission clearly. Thus, they can make easy statement about what needs to be done (Omar \& Hussin, 2013).

3. Intellectual stimulation: Leaders can easily direct their followers to find a new solution for old problems as well as encouraging them to be innovative in problem solving (Marn, 2012). Approaching old situation in a new way and no public critics on follower's mistake are the key elements for this dimension of transformational leadership (Boerner, Eisenbeiss, \& Griesser, 2007).

4. Individualized consideration: The leaders who have this dimension are able to describe and develop each of their followers' demands (Luthans \& Doh, 2012). Bass (1985) delineates it as "the degree of personal attention and encouragement of self-development a leader devotes to the employees" (Marn, 2012; p 28).

Aforementioned dimensions of transformational leadership are mostly associated with job satisfaction in analyzing a relationship between leaders and their followers. The effect of transformational leadership on job satisfaction of an organizational group has been clearly defined in many studies (Givens, 2008). One of them is Avolio and his associates (1999) study. They mention that transformational leadership can provide how leaders can get success and relationship with their group so that it sounds as positive effect for an organization. By this way, transformational leadership enhances group awareness, renders people encouragement possible for good of employee's job satisfaction (Bryant, 2003).

\subsection{Relationship between Transformational and J ob Satisfaction}

Many studies which have examined leadership styles and job satisfaction have concluded that there is a strong relationship between transformational leadership and employee's job satisfaction and these two variable are correlated positively (Medley \& Larochelle, 1995; Leary, Sullivan \& Ray, 1990). They also stress that transformational leadership is the best way to identify interaction between employee and supervisor and it has a key role for being a part of fostering and stimulating information exchange for creation of highly satisfied employees in an organization, which contributes to the accomplishment of an organization (Lim \& Ployhart, 2004; Ash, 1997; Marn, 2012).

$$
\Rightarrow
$$

Transformational Leadership

1. Idealized Influence (attributed)

2. Idealized Influence (behavior)

3. Inspirational Motivation

4. Intellectual Stimulation

5. Individualized Consideration

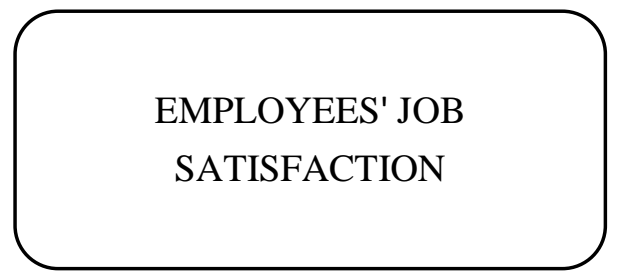

Figure 1. Conceptual Framework

According to previous researches, success of an organization is mostly associated with work of satisfied employees. Therefore, most of them focus on the factors which foster high job satisfaction. One of these factors is transformational leadership. Literature demonstrates highly positive interaction between the dimensions of transformational leadership and subordinates' job satisfaction (Omar \& Hussin, 2013). This interaction has also significant role for educational organizations (Leary, Sullivan, \& Ray, 1990). For instance, Bass (1990), Wilkins \& Balakrishnan (2013), and Basham (2012) stated that studies on transformational leaderhip in higher education suggest organizations to consider these leaders as organizational role models. In this way, 
intellectually inspired atmosphere by transformational leaders in higher educational institutions provides trust and cooperation among employees and thus increases job satisfaction (Wilkins \& Balakrishnan, 2013; Baltaci, Kara, Tascan, \& Avsalli, 2012; Sohail \& Delin, 2013). Higher educational institutions which have these satisfied employees with their job can provide high quality education for the students (Riaz \& Haider, 2010; Northouse, 2007; Ngadiman, Eliyana, \& Ratmawati, 2013). This study will examine the relationship between job satisfaction and transformatinal leadership at ptivate universities in Bosnia and Herzehovina.

According to the literature mentioned above, the hypotheses are as follows:

H1: Idealized influence (attributed) has a positive influence on employees' overall job satisfaction at private universities in $\mathrm{BiH}$ ?

H2: Idealized influence (behavior) has a positive influence on employees' overall job satisfaction at private universities in $\mathrm{BiH}$ ?

H3: Inspirational motivation has a positive influence on employees' overall job satisfaction at private universities in $\mathrm{BiH}$ ?

H4: Intellectual Stimulation has a positive influence on employees' overall job satisfaction at private universities in $\mathrm{BiH}$ ?

H5: Individualized Consideration has a positive influence on employees' overall job satisfaction at private universities in $\mathrm{BiH}$ ?

\section{Methodology}

2.1. Research Design and Instrumentation

A two-page questionnaire with three sections was used to collect data for the study. The first section included 20 questions about transformational leadership. A Multifactor Leadership Questionnaire (MLQ) developed by Avolio and Bass (1995) was conducted to measure respondents' perception about transformational leadership behavior toward their superiors. Transformational leadership consists of five dimensions that represented by 20 items. Each of them contains four items; idealized influence (attributed) illustrates 'instils pride in me for being associated with him/her', idealized influence (behavior) illustrates 'talks about their most important values and beliefs', inspirational motivation illustrates 'talks optimistically about the future', intellectual stimulation illustrates 're-examines critical assumptions to question whether they are appropriate', individualized consideration illustrates 'spends time for teaching and coaching'. It was used in several studies and their reliability was from 0.81 to 0.94 (Avolio et al., 1999; Bass, 1999).

Second part was designed to measure Overall J ob Satisfaction developed by Udge, Bono, \& Locke (2000). It measures the employees' job satisfaction. It was also used in some studies. The reliability of this scale was a $=.92$ (J udge, Bono, \& Locke, 2000). In all scales, the questions were measured with a five-point Likert scale, with scale anchors ranging from 1 (strongly disagree) to 5 (strongly agree).

Finally, the last part consisted of the respondents' demographic information such as age, gender, position in concerned institution, educatonal degree, their experience in current work and total work experience.

\subsection{Sample and Procedure}

The target group of respondents included employees from academic and administrative staff of private universities in $\mathrm{BiH}$. A total of 150 questionnaires were distributed to selected private universities. 120 of them responded to the survey, resulting in an 80 percent response rate. The questionnaire included both English and Bosnian versions. The back-translation mathod (Brinlin et al., 1973) was adopted to translate the survey from English to Bosnian. The translators were experts in a university's language translation department. Any items that looked ambiguous or difficult to understand were corrected before distribution.

A summary of the sample properties was given in Table $1.55 .8 \%$ of the respondents were male. Regarding age, the largest age group (30\%) was 31-35 years with. A big part of the participants (41.7\%) had master degree due to reason that more than half of the respondents were from academic staff with $60.8 \%$. In terms of the work experience, $74.2 \%$ of them were employed for less than 5 years in current position and more than half (52.5\%) had experience for less than 5 years in total. The data, especially, the descriptive analysis of the data, were analysed using SPSS (v. 20) software packages. The results are presented in the next section. 
Table 1: Sample Characteristics

\begin{tabular}{|c|c|c|c|}
\hline Variable & Demographics & Number & Valid percent \\
\hline Gender & $\begin{array}{l}\text { Male } \\
\text { Female } \\
\text { Total } \\
\end{array}$ & $\begin{array}{c}67 \\
53 \\
120 \\
\end{array}$ & $\begin{array}{c}55.8 \\
44.2 \\
100 \\
\end{array}$ \\
\hline Age & $\begin{array}{l}20 \text { years or below } \\
21-25 \text { years } \\
26-30 \text { years } \\
31-35 \text { years } \\
36-40 \text { years } \\
41 \text { years or above } \\
\text { Total } \\
\end{array}$ & $\begin{array}{c}0 \\
11 \\
30 \\
36 \\
25 \\
18 \\
120 \\
\end{array}$ & $\begin{array}{c}0 \\
9.2 \\
25 \\
30 \\
20.8 \\
15 \\
100 \\
\end{array}$ \\
\hline Position & $\begin{array}{l}\text { Academic staff } \\
\text { Administrative staff } \\
\text { Total } \\
\end{array}$ & $\begin{array}{c}73 \\
47 \\
120 \\
\end{array}$ & $\begin{array}{c}60.8 \\
39.2 \\
100 \\
\end{array}$ \\
\hline Degree & $\begin{array}{l}\text { High School } \\
\text { Bachelor Degree } \\
\text { Master Degree } \\
\text { Doctorate Degree } \\
\text { Total } \\
\end{array}$ & $\begin{array}{c}16 \\
38 \\
50 \\
16 \\
120 \\
\end{array}$ & $\begin{array}{l}13.3 \\
31.7 \\
41.7 \\
13.3 \\
100 \\
\end{array}$ \\
\hline $\begin{array}{l}\text { Experience in current } \\
\text { job }\end{array}$ & $\begin{array}{l}\text { Less than } 5 \text { years } \\
5 \text {-10 years } \\
10 \text {-15years } \\
\text { More than } 15 \text { years } \\
\text { Total } \\
\end{array}$ & $\begin{array}{c}89 \\
30 \\
1 \\
0 \\
120 \\
\end{array}$ & $\begin{array}{c}74.2 \\
25 \\
0.8 \\
0 \\
100 \\
\end{array}$ \\
\hline Experience in total & $\begin{array}{l}\text { Less than } 5 \text { years } \\
\text { 5-10 years } \\
\text { 10-15 years } \\
\text { More than } 15 \text { years } \\
\text { Total }\end{array}$ & $\begin{array}{c}63 \\
35 \\
7 \\
15 \\
120\end{array}$ & $\begin{array}{c}52.5 \\
29.2 \\
5.8 \\
12.5 \\
100\end{array}$ \\
\hline
\end{tabular}

\subsection{Data Analysis and Results}

The construct validity of two scales was checked with exploratory factor analysis by analysing the initial factor structure (Churchill, 1979). From two variables, the transformational leadership scale with 20 items were analysed firstly. Following a three-step process, a clear structure of dimensions and items was achieved. In the analysis, principal component analysis was used as the factor extraction method, and the varimax method was used for the component rotations. After the three runs, three items in this scale was removed from further analysis due to cross-loading on two components. Item excluded from analyses are "treats me as an individual rather than just as a member of a group", "considers me as having different needs, abilities, and aspirations from others" and " helps me to develop my strengths". Thus, 17 items with five dimensions emerged.

The remaining factor structure is presented in Table 2. One indication of the reliability of the dimensions is that the Cronbach alpha value exceeds .70 mostly (Nunnally, 1978). Secondly, job satisfaction scale was analysed. In this analysis, two dimensions emerged in convenient with the literature: nature of work and operating conditions (Spector, 1985). The Cronbach alpha value in this variable was also more than 70 mostly. 
Table 2: Results of Exploratory Factor Analysis

\begin{tabular}{|c|c|c|c|c|c|c|}
\hline \multirow{2}{*}{ Components and Items } & \multicolumn{5}{|c|}{ Components } & \multirow{2}{*}{$\begin{array}{c}\text { Cronbach's } \\
\text { Alpha }\end{array}$} \\
\hline & 1 & 2 & 3 & 4 & 5 & \\
\hline \multicolumn{7}{|l|}{ TRANSFORMATIONAL LEADERSHIP } \\
\hline Idealized Influence (attributed) & & & & & & 0,792 \\
\hline 1. instills pride in me for being associated with him/her & 0,812 & & & & & \\
\hline 2. acts in ways that builds my respect & 0,783 & & & & & \\
\hline 3. goes beyond self-interest for the good of the group & 0,769 & & & & & \\
\hline 4. displays a sense of power and confidence & 0,666 & & & & & \\
\hline Idealized Influence (behavior) & & & & & & 0,837 \\
\hline $\begin{array}{l}\text { 5. gets me to look at problems from many different } \\
\text { angles }\end{array}$ & & 0,873 & & & & \\
\hline $\begin{array}{l}\text { 6. suggests new ways of looking at how to complete } \\
\text { assignments }\end{array}$ & & 0,786 & & & & \\
\hline 7. seeks differing perspectives when solving problems & & 0,759 & & & & \\
\hline Inspirational Motivation & & & & & & 0,715 \\
\hline 8. talks optimistically about the future & & & $\begin{array}{c}0,80 \\
8\end{array}$ & & & \\
\hline $\begin{array}{l}\text { 9. talks enthusiastically about what needs to be } \\
\text { accomplished }\end{array}$ & & & $\begin{array}{c}0,68 \\
3\end{array}$ & & & \\
\hline 10. articulates a compelling vision of the future & & & $\begin{array}{c}0,65 \\
7\end{array}$ & & & \\
\hline $\begin{array}{l}\text { 11. emphasizes the importance of having a collective } \\
\text { sense of mission }\end{array}$ & & & $\begin{array}{c}0,55 \\
1\end{array}$ & & & \\
\hline Intellectual Stimulation & & & & & & 0,715 \\
\hline $\begin{array}{l}\text { 12. considers me as having different needs, abilities, and } \\
\text { aspirations from others }\end{array}$ & & & & 0,832 & & \\
\hline $\begin{array}{l}\text { 13. treats me as an individual rather than just as a } \\
\text { member of a group }\end{array}$ & & & & 0,676 & & \\
\hline 14. helps me to develop my strengths & & & & 0,633 & & \\
\hline $\begin{array}{l}\text { 15. considers the moral and ethical consequences of } \\
\text { decisions }\end{array}$ & & & & 0,503 & & \\
\hline Individualized Consideration & & & & & & 0,623 \\
\hline 16. expresses confidence that goals will be achieved & & & & & $\begin{array}{c}0,69 \\
5\end{array}$ & \\
\hline $\begin{array}{l}\text { 17. re-examines critical assumptions to question whether } \\
\text { they are appropriate }\end{array}$ & & & & & $\begin{array}{c}0,69 \\
5\end{array}$ & \\
\hline JOB SATISFACTION & & & & & & \\
\hline
\end{tabular}




\begin{tabular}{|c|c|c|c|}
\hline Nature of Work & & & 0,838 \\
\hline 1. Most days I am enthusiastic about my work & 0,904 & & \\
\hline 2. I feel fairly satisfied with my present job & 0,847 & & \\
\hline 3. I find real enjoyment in my work & 0,845 & & \\
\hline Operating Conditions & & & 0,674 \\
\hline 4. Each day at work seems like it will never end & & 0,88 & \\
\hline 5. I consider my job to be rather unpleasant & & 0,848 & \\
\hline \multicolumn{4}{|l|}{ Extraction Method: Principal Component Analysis. } \\
\hline \multicolumn{4}{|c|}{ Rotation Method: Varimax with Kaiser Normalization. } \\
\hline
\end{tabular}

The correlations between dimensions have always been good indicators of the discriminant validity of scales. In checking this, means from the items making up each dimension were created and the bivariate correlations were analysed. The correlations among the variables and descriptive statistics for them can be found in Table 3. As expected, nature of work dimension of job satisfaction is significantly correlated with all transformational leadership variables.

Table 3: Means, standard deviations, and correlations of study variables

\begin{tabular}{llllllllll}
\hline Variable & Mean & S.D. & 1 & 2 & 3 & 4 & 5 & 6 \\
\hline & & & & & & & & & \\
Job Satisfaction (nature of work) & 4.00 & .88 & 1 & & & & & \\
Job Satisfaction (operating conditions) & 3.97 & .89 & .172 & 1 & & & & \\
Idealized Influence (attributed) & 4.06 & .73 & $.370^{* *}$ & $.170^{* *}$ & 1 & & & \\
Idealized Influence (behavior) & 4.14 & .75 & $.331^{* *}$ & $.235^{* *}$ & $.502^{* *}$ & 1 & & \\
Inspirational Motivation & 4.14 & .76 & $.331^{* *}$ & $.235^{* *}$ & $.502^{* *}$ & $1.00^{* *}$ & 1 \\
Intellectual Stimulation & 3.86 & .87 & $.281^{* *}$ & .130 & $.316^{* *}$ & $.240^{* *}$ & $.240^{* *}$ & 1 \\
Individualized Consideration & 3.88 & .87 & $.328^{* *}$ & .135 & $.371^{* *}$ & $.348^{* *}$ & $.348^{* *}$ & $.529^{* *}$ & 1 \\
& & & & & & & & &
\end{tabular}

Regression analyses were carried out to test the hypothesized relationships between the dimensions of transformational leadership and job satisfaction components. The results are summarized in Table 4. All five dimensions of transformational leadership were found to be significant and positively related to job satisfaction (nature of work and operating conditions). In testing Hypotheses 1, 2, 3, 4 and 5, the transformational leadership dimensions regressed on job satisfaction's two dimensions. Coefficients for idealized influence (attributed) (.370), idealized influence (behavior) (.331), inspirational motivation (.331), intellectual stimulation (.281), individualized consideration (.328) and nature of work job satisfaction were satisfied.

Table 4: Regression analysis of transformational leadership and job satisfaction

\begin{tabular}{lcccr}
\hline \multicolumn{3}{c}{ Job Satisfaction } & & \\
\hline Criterion Variables & Nature of Work & Operating Conditions & & \\
& Std. Beta & Std. Beta & p-value & p-value \\
\hline Transformational Leadership & & & & \\
1. Idealized Influence (attributed) & .370 & .170 & .000 & .063 \\
2. Idealized Influence (behavior) & .331 & .235 & .000 & .010 \\
3. Inspirational Motivation & .331 & .235 & .000 & .010
\end{tabular}




\section{Intellectual Stimulation}

5. Individualized Consideration
.281

.328
.130

.135
.002

.000
.158

.142

Note: $\mathrm{N}=120 ; \mathrm{p}<.05, \mathrm{R}^{2}$, Beta $=$ Standardized beta coefficients

Secondly, job satisfaction of employees with operating conditions was also regressed on transformational leadership dimensions. Results were satisfactory mostly. Namely, the relationship between idealized influence (attributed) (.170), idealized influence (behavior) (.235), inspirational motivation (.235) and operating conditions job satisfaction was significant and positively related. These findings supported H1, H2, and H3. But, the relationship between intellectual stimulation (.130) and individual consideration (.135) and operating conditions job satisfaction was not significant. Thus, these findings did not support $\mathrm{H} 4$ and $\mathrm{H} 5$.

Table 5: Summary of Hypotheses Results

\begin{tabular}{|l|l|l|}
\hline H1 & $\begin{array}{l}\text { Idealized influence (attributed) has a positive influence on employees' overall } \\
\text { job satisfaction at private universities in BiH? }\end{array}$ & Supported \\
\hline H2 & $\begin{array}{l}\text { Idealized influence (behavior) has a positive influence on employees' overall } \\
\text { job satisfaction at private universities in BiH? }\end{array}$ & Supported \\
\hline H3 & $\begin{array}{l}\text { Inspirational motivation has a positive influence on employees' overall job } \\
\text { satisfaction at private universities in BiH? }\end{array}$ & Supported \\
\hline H4 & $\begin{array}{l}\text { Intellectual Stimulation has a positive influence on employees' overall job } \\
\text { satisfaction at private universities in BiH? }\end{array}$ & Not Supported \\
\hline H5 & $\begin{array}{l}\text { Individualized Consideration has a positive influence on employees' overall job } \\
\text { satisfaction at private universities in BiH? }\end{array}$ & Not Supported \\
\hline
\end{tabular}

\subsection{Discussion}

The purpose in this study was to examine the perceptions of transformational leadership behaviors on employees' job satisfaction at private universities in $\mathrm{BiH}$. The findings showed that transformational leadership has a positive relationship on employees' job satisfaction. In particular, the dimensions of transformational leadership and job satisfaction were positively correlated with each other and the relationship between them was significant mostly. So, this study obtained evidence to support the use of transformational leadership to enrich and increase employees' job satisfaction in work in convenient with others (Voon \& Ayob, 2011; Thamrin, 2012; Tesfaw, 2014; Sohail \&Delin, 2013; Riaz \&Haider, 2010; Omar \&Hussin, 2013).

According to results, all hypotheses were positively correlated with nature of work - job satisfaction. On the other hand, even though first three dimensions of transformational leadership were significant and positively correlated with operating conditions - job satisfaction, intellectual stimulation and individualized consideration were insignificant with it. These findings show that employees are highly satisfied with specific goals in working place: nature of work. But, their work assignment, operating condition, should be re-checked for higher job satisfaction. Bosnian context may be a reason for this result. $\mathrm{BiH}$ is a transitional country and economic situation in this country is weak and the unemployment rate is very high. So, people do not have so many alternatives to work. Under this condition, employees do not like their job and job content mostly. However, the structure and tracking procedure of jobs have been developed after the conflict ended in 1995. And, the private universities have been established in the last decade in this transitional country. Employees at these universities are not experienced mostly as it can be seen in demographic results of the study. At this point, the managers of administrative units and head of departments at these universities should organize some trainings in order to improve their managerial skills.

They should also be more careful for choosing the most suitable job and task for their employees. This enables the organizational unit of the employees to be more productive.

Although intellectual stimulation and individualized consideration dimensions have positive relationships with job satisfaction, they are weak. Leaders should pay more attention to be innovative and problem solver for intellectual stimulation characteristic and they should also be more sensitive on employees' encouragement of self-development for individualized consideration 
characteristic. Leaders should be a role model in creation of new ideas and in taking their followers' ideas and demands into consideration in universities' decision making process. Thus, it may help the incensement of employees' job satisfaction (Tesfaw, 2014).

To sum up, transformational leadership style, generally, has a positive effect on employees' job satisfaction at private universities in $\mathrm{BiH}$. So, this research model can be used for other institutions such as public universities and governmental institutions in $\mathrm{BiH}$ so that managers can develop their managerial and leadership skills.

4.2. Limitations and Further Research

This research is limited to only two private universities in $\mathrm{BiH}$. Having small size of respondents is also limitation of this research. Collecting data from other private universities in $\mathrm{BiH}$ can give more reliable results in future studies. Moreover, in this study, the data was collected from only full-time employees at the universities. It may not be deemed suitable for a proportional transformational leadership model. Part-time employees can be included in future studies in order to overcome that issues. Future studies should also focus on the private and public universities in $\mathrm{BiH}$ and findings of these universities should be compared.

\section{References:}

1. Amin, Muhammad (2012). The Relationship of Principals/ Directors' Leadership Styles, as Perceived by the Faculty, to the J ob Satisfaction of the Faculty Members in a Public University of Punjab, Pakistan. Dissertation for the degree of doctor of education, University of Leicester.

2. Amoroso, Paul F. (2002). The Impact of Principals' Transformational Leadership Behaviors on Teacher Commitment and Teacher J ob Satisfaction. Dissertation for the degree of doctor of education, Seton Hall University Dissertations and Thesis (ETDs).

3. Ash, B. David (1997). Transformational Leadership and Organizational Learning: Leader Actions that Stimulate Individual and Group Learning. Dissertation for the degree of doctor of education. Ball State University.

4. Atmojo, M. (2012). The Influence of Transformational Leadership on J ob Satisfaction, Organizational Commitment, and Employee Performance. International Research J ournal of Business Studies vol. V no. 02, 113-128.

5. Avolio, B.J., Bass, B.M., \& Jung, D.I. (1999). Re-examining the Components of Transformational and Transactional Leadership using the Multifactor Leadership Questionnaire. J ournal of Occupational and Organizational Psychology, 441-462.

6. Avolio, B., Walumbwa, F., \& Weber, T. (2009). Leadership: Current Theories, Research, and Future Directions. Annual Review of Psychology, 421-449.

7. Awamleh, R., \& Al-Dmour, H. (2004). The Impact Of Transformational Leadership On J ob Satisfaction And Self-Perceived Performance Of Banking Employees: The Case Of J ordan. International Business \&Economics Research J ournal, Vol. 3, No. 11, 29-42.

8. Baltaci, F., Kara, E., Tascan, E., \& Avsalli, H. (2012). The Effects of Leadership On J ob Satisfaction. 3rd International Symposium on Sustainable Development (pp. 220-226). Sarajevo: International Burch University.

9. Basham, L. (2012). Leadership in Higher Education. Journal of Higher Education Theory and Practice, Vol. 12, No. 6, 54-58.

10. Bass, B. (1997). Does the Transactional - Transformational Leadership Paradigm Transcend Organizational nad National Boundaries. American Psychologist, Vol 52, No. 2, 130-139.

11. Bass, B. (1999). Two Decades of Research and Development in Transformational Leadership. European J ournal of Work and Organizational Psychology, Vol. 8, No: 1, 9-32.

12. Bass, B.M. (1990). From Transactional to Transformational Leadership: Learning to Share the Vision. Organizational Dynamics, Vol. 18, No. 3, 19-31.

13. Bateman T. S. and Organ D. W. (1983), Job Satisfaction and the Good Soldier: The Relationship between Affect and Employee Citizenship, Academy of Management J ournal, Vol. 26 (4): 587-595.

14. Belias, D., \& Koustelios, A. (2014). Transformational Leadership and J ob Satisfaction in the Banking Sector: A Review. International Review of Management and Marketing, Vol. 4, No. 3, pp.187-200. 
15. Boerner, S., Eisenbeiss, S. A., \& Griesser, D. (2007). Follower Behavior and Organizational Performance: The Impact of Transformational Leaders. J ournal of Leadership and Organizational Studies, Vol. 13, No. 3, 15-26. 634-638.

16. Bota, O. (2013). J ob Satisfaction of Teachers. Procedia - Social and Behavioral Sciences,

17. Bryant, S. (2003). The Role of Transformational and Transactional Leadership in Creating, Sharing and Exploiting Organizational Knowledge. The J ournal of Leadership and Organizational Studies, Vol. 9, No.4, 32-43.

18. Campbell, M. (2012). Transformational Rest for Educators. Christian Education J ournal, Vol. 9, No. 1, 194-205.

19. Christina, L. (2014). Employee Job Satisfaction and Engagement: The Road to Economic Recovery. Alexandria, VA: The Society for Human Resource Management.

20. Cohrs, J.C., Abele, A. E. and Dette, D. E. (2006), Integrating Situational and Dispositional Determinants of J ob Satisfaction: Findings from Three Samples of Professionalsl, The J ournal of Psychology, Vol. 140 (4): 363- 395.

21. Dubrin, A.J . (2013). Leadeship: Research Findings, Practice, and Skills, 7th ed. Mason, $\mathrm{OH}$ : South-Western Cengage Learning.

22. Fry, L. (2003). Toward a Theory of Spiritual Leadership. The Leadership Quarterly, Vol. 14, No: 6, 693-727.

23. Givens, R. (2008). Transformational Leadership: The Impact on Organizational and Personal Outcomes. Emerging LeadershipJ ourneys, Vol. 1, Iss. 1, 4-24.

24. Hanaysha, J. R., Khalid, K., Mat, N.K., Sarassina, F., Rahman, M.Y., \& Zakaria, A.S. (2012). Transformational Leadership and Job Satisfaction. American Journal of Economics, Special Issue, 145-148.

25. J ack, J ., \& Rudnick, J . (2007). Transformational Leadership: Model Encourages Leaders to Transcend Personal Ambition. Health Progress, Vol. 88, No. 3, 36 - 40.

26. Judge, T.A., Bono, J.E., \& Locke, E.A. (2000). Personality and Job Satisfaction: The Mediating Role of J ob Characteristics. J ournal of Applied Psychology, Vol. 85, No. 2, 237-249.

27. Kimura, T. (2012). Transformational Leadership and J ob Satisfaction: The Mediating Effects of Perceptions of Politics and Market Orientation in the J apanese Context. Int. J ournal of Business Science and Applied Management, Volume 7, Issue 1, 30-42.

28. Kuzey, Cemil (2012). Impact of Health Care Employees' J ob Satisfaction on Organizational Performance Support Vector Machine Approach, European J ournal of Economic and Political Studies, EJ EPS 5 (1)

29. Leary, P., Sullivan, M., \& Ray, D. (1990). The Relationship of Leadership Styles of Selected West Virginia Deans and Department Chairs to J ob Satisfaction of Departmental Faculty Members. National Forum of Educational Administration and Supervision, Vol. 16, No. 4, 33-41.

30. Lim, B.-C., \& Ployhart, R. (2004). Transformational Leadership: Relations to the FiveFactor Model and Team Performance in Typical and Maximum Contexts. J ournal of Applied Psychology, Vol. 89, No. 4, 610- 621.

31. Long, C.S., Yusof, W., Kowang, T., \& Heng, L. (2014). The Impact of Transformational Leadership Style on J ob Satisfaction. World Applied Sciences J ournal, 117-124.

32. Lorber, Mateja \& Savic, Brigita Skela (2012). J ob satisfaction of nurses and identifying factors of job satisfaction in Slovenian Hospitals. Croatian Medical J ournal, 53(3), 263- 270.

33. Luthans, F., \& Doh, J. (2012). International Management: Culture, Strategy, and Behavior. New York: McGraw-Hill.

34. Marn, J.T. (2012). The Impact of Transformational Leadership Practices on J ob Satisfaction of PHEI Lecturers. J ournal for The Advancement of Science and Arts, Vol. 3, No. 2, 26-39.

35. Medley, F., \&Larochelle, D.R. (1995). Transformational Leadership and J ob Satisfaction. Nursing Management, Vol. 26, No. 9, 64JJ - 64NN.

36. Mirkamali, S., Thani, F., \& Alami, F. (2011). Examining the Role of Transformational Leadership and J ob Satisfaction in the Organizational Learning of an Automotive Manufacturing Company. Procedia - Social and Behavioral Sciences, 139 -148.

37. Munir, R.I., Rahman, R., Malik, A., \& Ma'amor, H. (2012). Relationship between Transformational Leadership and Employees' Job Satisfaction among the Academic Staff. 
International Congress on Interdisciplinary Business and Social Science 2012 (pp. 885-890). J akarta: Elsevier Ltd.

38. Ngadiman, Eliyana, A., \& Ratmawati, D. (2013). Influence of Transformational Leadership and Organization Climate to The Work Satisfaction, Organizational Commitment and Organizational Citizenship Behavior on The Educational Personnel of Sebelas Maret Unıversity, Surakarta. Educational Research International, Vol. 1, No.1, 41-66.

39. Northouse, P. (2007). Leadership: Theory and Practice, 4th ed. Thousand Oaks, CA: SAGE.

40. Omar, W.W., \& Hussin, F. (2013). Transformational Leadership Style and Job Satisfaction Relationship: A Study of Structural Equation Modeling. International Journal of Academic Research in Business and Social Sciences, Vol. 3, No. 2, 346-365.

41. Peltier, J immy \& Dahly Andy (2009). The Relationship between Employee Satisfaction and Hospital Patient Experiences. Forum: For People Performance Management and Measurement.

42. Pool, S. W. (1997), The Relationship of J ob Satisfaction with Substitutes of Leadership, Leadership Behavior, and Work Motivationl, The J ournal of Psychology, Vol 131 (3): 271-283.

43. Podsakoff, P.M., MacKenzie, S.B., Moorman, R.H., and Fetter, R. (1990), Transformational Leader Behaviors and Their Effects on Followers' Trust in Leader, Satisfaction and Organizational Citizenship Behaviorsl, Leadership Quarterly, Vol. 1(2): 107-142.

44. Riaz, A., \& Haider, M. (2010). Role of Transformational and Transactional Leadership on J ob Satisfaction and Career satisfaction. BEH - Business and Economic Horizons, Volume 1, Issue 1, 29-38.

45. Shin, H., Reyes, P., 1991. Teacher commitment and job satisfaction: which comes first? (Report No. SP 033 402). American Educational Research Association, Chicago IL (Eric Document Reproduction Service No. ED 338 596).

46. Shrivastava, A., \& Purang, P. (2009). Employee Perception of Job Satisfacion: Comperative Study on Indian Banks. Asian Academy of Management J ournal, Vol. 1, 65-78.

47. Sohail, M.T., \& Delin, H. (2013). J ob Satisfaction Surrounded by Academics Staff: A Case Study of J ob Satisfaction of Academics Staff of the GCUL, Pakistan. Interdiciplinary J ournal of Contemporary Research in Business, Vol. 4, No. 11, 126-137.

48. Spector, P.E. (1985). Measurement of Human Service Staff Satisfaction: Development of the J ob Satisfaction Survey. American J ournal of Community Psychology, 693-713

49. Stewart, J. (2006). Transformational Leadership: An Evolving Concept Examined through the Works of Burns, Bass, Avolio, and Leithwood. Canadian J ournal of Educational Administration and Policy, 1-29.

50. Tesfaw, T. (2014). The Relationship between Transformational Leadership and J ob Satisfaction: The Case of Government Secondary School Teachers in Ethiopia. Educational Management Administration \& Leadership, Vol. 42, No. 6, 903-918.

51. Thamrin, H.M. (2012). The Influence of Transformational Leadership and Organizational Commitment on Job Satisfaction and Employee Performance. International J ournal of Innovation, Management and Technology, Vol. 3, No. 5, 566-572.

52. Voon, M., Lo, M., Ngui, K., \& Ayob, N. (2011). The Influence of Leadership Styles on Employees' J ob Satisfaction in Public Sector Organizations in Malaysia. International J ournal of Business, Management and Social Sciences, Vol. 2, No. 1, 24-32.

53. Walumbwa, F.O., Orwa, B., Wang, P, Lawler, J.J . (2005), Transformational Leadership, Organizational Commitment, and J ob Satisfaction: A Comparative Study of Kenyan and U.S. Financial Firms, Human Resource Development Quarterly, Vol. 16 (2): 235-256.

54. Webb, Xavier (2012). MeasuringJ ob Satisfaction among Kentucky Head Principals using the Rasch Rating Scale Model. Published Doctoral Thesis. Thesis and Dissertation: Educational Leadership Studies. USA: University of Kentucky.

55. Wilkins, S., \& Balakrishnan, M. (2013). Assessing Student Satisfaction in Transnational Higher Education. International J ournal of Educational Management, Vol. 27, No. 2, 143-156.

56. Yukl, Gary (2010). Leadership in Organizations. Seventh Edition. Upper Saddle River, NJ : Pearson/ Prentice Hall. 